\title{
藻類由来有機物に起因するセラミック膜 ファウリングの前塩素処理による抑制効果
}

\author{
八巻 哲也 ${ }^{1 *} \cdot \mathrm{Jae}-\mathrm{Lim} \mathrm{LIM}^{2} \cdot$ 吉原 $^{\text {康徳 }}{ }^{3} \cdot$ 米川 均 ${ }^{3} \cdot$ 大村 $^{\text {達夫 }}{ }^{1}$ \\ ${ }^{1}$ 東北大学大学院工学研究科（干980-8579 宮城県仙台市青葉区荒巻字青葉6-6-06）
}

${ }^{2}$ Korea Water Resources Corporation (462-1 Jeonmin-Dong, Yuseong-Gu Daejeon, Korea 305-730)

3 メタウォーター株式会社（干105-6029 東京都港区虎ノ門4-3-1）

* E-mail: yamaki-tt@n-koei.jp

\begin{abstract}
藻類由来有機物による膜ファウリングに対して, 前塩素処理の有効性を検討するため, セラミック膜を 用いた膜ろ過実験を行うとともに，塩素処理前後の化学特性及び分子量分布の測定を行った，その結果， 全ての塩素処理条件下で溶存有機炭素及び中性糖の濃度が上昇することが示された，一方で，たんぱく質 については, 4-8 $\mathrm{mg} \cdot \mathrm{L}^{-1}$ の塩素処理濃度でその濃度が減少する結果となった。 さらに, 分子量分布につい ては, 塩素処理により主要な分子量のピークが低分子に移動したことが示された。 また, 膜ろ過実験にお いては，全ての塩素処理条件下で不可逆的膜ファウリングが抑制されたことから，前塩素処理を行うこと で有機物が変性し，凝集フロックの形成に影響を与えたことで膜ファウリングが抑制されたと考えられた。
\end{abstract}

Key Words : algal organic matter, pre-chlorination, microfiltration, fouling, ceramic membrane

\section{1. はじめに}

私たちの生活を成り立たせるために，安全で衛生的な 水を得ることは必要不可久である. そして，そのような 水を得るために必要な水源や浄水処理施設は, 社会基盤 として重要な役割を果たしている. 近年, 数ある浄水処 理方法の中でも, 従来の砂万過法に代わる浄水技術とし て, 膜ろ過処理による浄水処理法が注目されている. そ の理由として, 膜処理は原水中の濁質を確実に除去する ことが可能であること，塩素処理に対して而性を持つ病 原性原虫（クリプトスポリジウムなど）に対しても厳密 な除去が可能であること卓が挙げられる．また，施設運 転上の観点から, 膜処理施設は自動運転が可能であるこ と, 従来の手法に比べて必要な用地が少ないことが挙げ られる2!.

一方で, 膜を長期的に用いることによって生じる膜の 透過性能劣化（膜ファウリング） は動力費・薬品洗浄費 など膜処理施設の稼働コストを押し上げている. ファウ リング解消のため, 膜処理の前段で何らかの前処理を行 うことは非常に有効なファウリング抑制方法であり, 特 に凝集処理はフロックを形成させることによって，ファ ウリングの発生を抑制することができる. 膜の種類によ
っては，大きなフロックを形成する必要が無く, インラ イン凝集を用いたマイクロフロックの形成で十分効果を 得られることが報告されている3゙. しかしながら，凝集 条件には注意が必要で, 不適当な条件で凝集を行うと, 逆にファウリングが促進されてしまう場合がある゙ た, 逆圧洗浄やエアバブリングといった物理的膜洗浄方 法が一定時間間隔で行われているが，物理的洗浄を定期 的に行っていても解消されないファウリングが発生して くる. これを不可逆的膜ファウリングという. 不可逆的 膜ファウリングは酸（クエン酸, 硫酸など) やアルカリ

（水酸化ナトリウム，次亜塩素酸ナトリウムなど）とい った薬品洗浄によって緩和され，運転コストに大きな影 響を与える.ささらに, 薬品洗浄は, 膜に損傷を与える可 能性があることに加えて, 洗浄に利用した薬品廃液の処 理が問題となることから，不可逆的膜ファウリングを抑 制することは，膜ろ過処理を長期的に運転する上で重要 な観点となる.

高分子膜ファウリングを引き起こす物質としては，親 水性物質の関与が指摘されており ${ }^{5,6}$, 多糖類様及びタン パク質様の有機物質が推定されている7゙. 特に多糖類様 有機物質は, 膜ろ過処理と併用される凝集沈殿処理によ って除去されにくいことが知られており ${ }^{8)}$, 膜ファウリ 
ングへの影響が多数報告されている ${ }^{9-11)}$. このように, 親水性物質による膜ファウリングへの影響が報告されて いる中で，特に閉鎖性水域を水源とした場合，藻類によ る膜ファウリングへの影響が課題になると考えられる.

藻類は代謝活動によって糖やタンパク質等の有機物を産 生し ${ }^{12}$ 13)，水中に放出するだけでなく, 藻類細胞自体も タンパク質や脂質で構成されており, 藻類が膜ファウリ ングへ与える影響は大きいと考えられる ${ }^{1417}$.

よって, 本研究では, 膜ファウリングを引き起こす物 質として，藻類由来有機物（Algal Organic Matter: AOM） に着目した. 従来の急速ろ過処理においては, 藻類対策 として前塩素処理を施すことで藻類を死滅させ凝集効率 を改善していたが，膜ろ過処理において前塩素処理を用 いた場合，藻類を死滅させる一方で，藻類細胞内の有機 物を水中に放出させることになり, 膜ファウリングへの 影響を単純には評価できない ${ }^{18200}$. そこで，本研究では 藻類含有水に対して前塩素処理を行った場合の有機物組 成の変化と, 前塩素処理による膜ファウリングへの影響 を検討することとした。

塩素処理前後の有機物の分析については, 中性糖・タ ンパク質等といった有機物の測定に加え, 中高速液体ク ロマトグラフィーによる分子量分布の測定を行った．ま た, 塩素処理による膜ファウリングへの影響を検討する ため, 藻類含有水に対して塩素処理を行った試料水を用 いて, 小型膜ろ過器による膜ろ過実験を行った.

\section{2. 実験方法}

\section{(1) 現地実験}

\section{a) 試料の調製}

本研究に用いる試料水として，2011年11月に韓国Aダ ム中層より採水した湖沼水（原水）を用いた. 採水時の 湖沼水中の全藻類細胞数は $1787 \mathrm{cell} \cdot \mathrm{mL}^{-1}$ であった. 採水

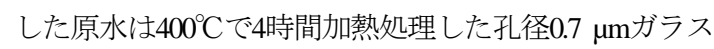
繊維ろ紙（GF/F，WHATMAN）を用いてろ過した。ま た，採水した湖沼水に次亜塩素酸ナトリウムを $1 ， 2 ， 4$, $6,8 \mathrm{mg} \cdot \mathrm{L}^{-1}$ となるように添加し, 塩素処理水を作製した。 これら塩素処理水は 15 分間静置後, 孔径 $0.7 \mu \mathrm{m} カ ゙ ラ ス$ 䋊 維万紙を用いてろ過した. 15分静置後の塩素濃度は, 1 $\mathrm{mg} \cdot \mathrm{L}^{-1}$ 塩素処理水で $0.2 \mathrm{mg} \cdot \mathrm{L}^{-1}, 2 \mathrm{mg} \cdot \mathrm{L}^{-1}$ 塩素処理水で 1.0 $\mathrm{mg} \cdot \mathrm{L}^{-1}, 4-8 \mathrm{mg} \cdot \mathrm{L}^{-1}$ 塩素処理水で $2.0 \mathrm{mg} \cdot \mathrm{L}^{-1}$ 以上であった. 上記試料水は凍結後, 実験室に輸送した. 凍結乾燥を行 うためには試料の濃縮を行う必要があったため, 試料水 は自然解凍させ，ロータリーエバポレーター（RE111, SHIBATA）で濃縮を行った後, 凍結乾燥機（DC800, Yamato）を用いて乾燥試料とした.

\section{b) 水質分析}

原水水質の把握のため, 採水時に濁度, UV254, 全Fe, 全Mnの測定を行った。濁度は携帯濁度計（2100P， HACH）を用いて測定を行った. UV254は0.45 $\mu \mathrm{m}$ のフィ ルターを用いて試料水のろ過を行った後, 水質分析計

（DR5000，HACH）を用いて測定を行った ${ }^{19}$ ． 全Feは 1,10-phenanthroline法 2, 23)，全Mnは1-(2-Pyridylazo)-2-Naphthol 法 ${ }^{24}$ により測定を行った. 濁度・UV254・全 $\mathrm{Fe} ・$ 全 $\mathrm{Mn}$ の 測定は全て3回行い, 母集団偏差を算出した.

\section{(2) 組成分析}

\section{a) 組成分析}

原水及び1-8 $\mathrm{mg} \cdot \mathrm{L}^{-1}$ の塩素処理水の成分特性を評価す るため, 糖質 (中性糖) ・タンパク質・脂質・DOCの 測定を行った. 乾燥試料は超純水に溶解させ測定に用い たが，乾燥試料は超純水に一部不溶であったため，乾燥 試料を超純水に懸濁させ超音波処理（50W, 1分）を行っ た後, 分析に供した ${ }^{25}$. 糖質（中性糖）はフェノール-硫 酸法 ${ }^{26,27}$, タンパク質はDc Protein Assayキット（BIORAD）を用いたLowry法 ${ }^{28)}$ ，脂質はLab Assay Triglyceride kit （Wako）を用いたGPO-DAOS法29)により測定した。また, DOCは全有機炭素計（TOC-5000A，SHIMADZU）を用い て測定を行った.

\section{b) 分子量分画}

試料水の分子量分布を把握するため, 分子量分画をゲ ルろ過クロマトグラフィーにより行った. 分析には, 中 高圧液体クロマトグラフィー（ÄKTApurifier， GE Healthcare）及びゲルろ過クロマトグラフィーカラム (Superdex75 10/300 GL， $\Phi 1.0 \times 30 \mathrm{~cm}$, GE Healthcare) を 用い, 示差屈折率検出器 (RI-8020, TOSOH) 及び紫外 線吸光度 $(280 \mathrm{~nm})$ で検出した. 乾燥試料は緩衝溶液で ある50 $\mathrm{mM}$ 重炭酸アンモニウム水溶液 $(\mathrm{pH} 8.0 \pm 0.05$, 関東化学) に溶解させ，分析に供したが，乾燥試料は緩 衝溶液に不溶であったため, 乾燥試料を緩衝溶液に懸濁 させ超音波処理（50W, 1分）を行った後，分析に供した。

\section{(3) 膜ろ過実験 \\ a) 実験装置概要}

膜ろ過実験装置は, 急速擋汼槽と緩速摚拌槽を持つ凝 集槽と，膜ろ過を行う膜ろ過装置から構成される．凝集 槽では, 外部ポンプを用いて塩素及び疑集剂を添加する ことが可能である．膜ろ過装置の運転方式は定流量デッ トエンド方式であり, 定期的に自動で逆洗が可能となっ ている. ろ過圧力は, 膜モジュールの上流側に設置した ろ過前圧力計と下流側に設置したろ過後圧力計で計測さ れた圧力差として求められる. 膜には, 小型実験用の膜 面積0.0346 $\mathrm{m}^{2}$, 膜細孔径 $0.1 \mu \mathrm{m}$ のセラミック製エレメン 
トを用いた。 また，運転工程は次の工程により構成され る.（i）原水供給ポンプが作動して膜エレメント内に 原水が充填される.（ii）定流量ろ過が開始される.

(iii) 万過の停止後, 逆圧洗浄水による洗浄が行われる.

(iv) エアフラッシュによる洗浄が行われる. 以上の運 転を 1 サイクルとして, 膜ろ過装置の運転が繰り返され る.

\section{b) 膜ろ過実験}

実験に用いる試料水として，2011年11月に大韓民国A ダム中層から取水した湖沼水を用いた. この湖沼水に対 して, 凝集槽流入前に次亜塩素酸ナトリウムを添加し, 前塩素処理を行った. 添加量は塩素処理の効果を明確に するために，塩素濃度が $0 ， 1 ， 2 ， 4 ， 6 ， 8 \mathrm{mg} \cdot \mathrm{L}^{-1}$ となる ように添加し，それぞれの試料水名を原水（次亜塩素酸 ナトリウム添加無し）， $1 \mathrm{mg} \cdot \mathrm{L}^{-1}$ 塩素処理水, $2 \mathrm{mg} \cdot \mathrm{L}^{-1}$ 塩 素処理水, $4 \mathrm{mg} \cdot \mathrm{L}^{-1}$ 塩素処理水, $6 \mathrm{mg} \cdot \mathrm{L}^{-1}$ 塩素処理水, 8 $\mathrm{mg} \cdot \mathrm{L}^{-1}$ 塩素処理水とした.

凝集槽における擋汼条件として, G值 $123 \mathrm{~s}^{-1}$ の急速摚 拌槽における滞留時間を5分, $\mathrm{G}$ 值43 $\mathrm{s}^{-1}$ の緩速摚汼槽に おける滞留時間を10分とした. 原水のpHは7.7-7.8であっ た.また，膜ろ過装置の実験条件として流量を $5.0 \mathrm{~m}^{3} \cdot \mathrm{m}$ ${ }^{2} \cdot$ day $^{-1}$ とし，凝集剂 $(\mathrm{PACl})$ が $1.5 \mathrm{mg}-\mathrm{Al} \cdot \mathrm{L}^{-1}$ となるように 添加した．定流量ろ過の継続時間は3分とし，逆洗時間 は20秒とした.

\section{3. 結果と考察}

\section{(1) 組成分析結果}

サンプリング時に測定した試料水中の濁度・UV254・ 全 $\mathrm{Fe}$ ・全Mnの測定結果を表-1に示す．塩素処理を行っ たことにより，全ての塩素処理水において濁度・UV254 が一様に減少したことが示された. 波長 $254 \mathrm{~nm}$ 紫外線 は不飽和結合を有する有機物により特異的に吸光される ため, UV254は水中の有機性污濁や浄水処理過程の処理 性評価に用いられている. 塩素処理によってUV254の測 定值が減少したことから，試料水中に溶存している不飽 和結合を有する有機物が減少したこと，すなわち塩素処 理により不飽和結合が分解されたことが考えられた。一 方, UV254の測定結果は塩素処理濃度によって変化がな
いことから，塩素によって切断される不飽和結合の種類 が限られていたと考えられた，また，塩素処理によって 濁度も減少したが，この点については，塩素処理による 酸化分解や二重結合の開裂が生じ，その結果，光散乱領 域の粒子サイズが低下したり, 対象物の屈折率が変化し て濁度減少につながったと推測された。全Fe及び全Mn 濃度に関しては，ダム中層から採水したため顕著に高い 值は示さず, 数時間程度の短期的な膜ファウリングに影 響を及ぼす濃度ではないと考えられた，また，塩素処理 により全Mnの濃度が一様に減少しているが，これは自 然水中に存在する溶解性Mnが塩素と錯形成反応するこ とで，1-(2-Pyridylazo)-2-Naphthol法による錯形成反応を阻 害したためと考えられる.

次に化学組成の分析結果 (DOC・糖類・タンパク 質）を図-1に示した. まずDOCについては，全ての塩素 処理水のDOC濃度が原水のDOC濃度を上回った。 その 理由としては，塩素処理が藻類及び微生物の細胞に影響 を与え, 細胞表面もしくは細胞内部の有機物が水中に放 出されたためと考えられる. 同時に, $0.7 \mu \mathrm{m}$ のフィルタ 一を透過することが出来なかった原水中の藻類及び微生 物由来有機物が，塩素処理によってサイズ低下及び低分 子化されたことでフィルターを透過し, DOCの増加を もたらしたとも考えられる，中性糖濃度に関しては，測 定結果にばらつきがあり，塩素処理による影響は見られ なかった。 しかし, 塩素処理によりDOCが増加してい ることから, 塩素処理が原水中の藻類や微生物に影響を 与えたことが考えられ, 細胞内・表面に存在する糖が水 中に溶出したことが考えられる. 一方で, 塩素濃度が4 $\mathrm{mg} \cdot \mathrm{L}^{-1}$ 以上であった場合, タンパク質濃度が減少した。 タンパク質濃度の測定に用いたLowry法は，酒石酸塩を 含むアルカリ条件下で $\mathrm{Cu}^{2+}$ がタンパク質のペプチド結合 と結合することで $\mathrm{Cu}^{+}$となり，次に銅とタンパク質の結 合物がFolin phenol試薬と反応することで青色に発色する (750 nm) . すなわち，Lowry法によるタンパク質の定 量はペプチド結合によるものであるため，塩素濃度が4 $\mathrm{mg} \cdot \mathrm{L}^{-1}$ 以上である場合にタンパク質濃度が減少したこと は, 試料水中のタンパク質が高濃度の塩素によってペプ チド結合が切断されたためと考えられる. また，タンパ ク質のペプチド結合が切断されたことで, その分子量も 小さな物質に分解されたされたと推測される. 一方, ヘ

表-1 水質分析結果

\begin{tabular}{ccccccccc}
\hline & \multicolumn{2}{c}{ 濁度 $(\mathrm{NTU})$} & \multicolumn{2}{c}{$\mathrm{UV} 254\left(\mathrm{~cm}^{-1}\right)$} & \multicolumn{2}{c}{ 全Fe $\left(\mathrm{mg}^{-} \mathrm{L}^{-1}\right)$} & \multicolumn{2}{c}{ 全 $\mathrm{Mn}\left(\mathrm{mg}^{-} \mathrm{L}^{-1}\right)$} \\
\cline { 2 - 9 } 試料水 & 平均値 & 標準偏差 & 平均値 & 標準偏差 & 平均値 & 標準偏差 & 平均値 & 標準偏差 \\
\hline 原水 & 3.04 & 0.02 & 0.049 & 0.001 & 0.04 & 0.01 & 0.071 & 0.004 \\
$1 \mathrm{mg} /$ L塩素 & 2.06 & 0.02 & 0.027 & 0.001 & 0.07 & 0.01 & 0.047 & 0.002 \\
$2 \mathrm{mg} /$ L塩素 & 2.14 & 0.02 & 0.025 & 0.001 & 0.03 & 0.00 & 0.051 & 0.006 \\
$4 \mathrm{mg} /$ L塩素 & 2.29 & 0.07 & 0.024 & 0.001 & 0.04 & 0.01 & 0.045 & 0.003 \\
$6 \mathrm{mg} /$ L塩素 & 2.35 & 0.04 & 0.030 & 0.003 & 0.05 & 0.01 & 0.048 & 0.002 \\
$8 \mathrm{mg} /$ L塩素 & 2.29 & 0.02 & 0.028 & 0.002 & 0.04 & 0.01 & 0.045 & 0.001 \\
\hline
\end{tabular}


プチド結合が切断され，細分化されたアミノ酸が試料水 中に増加したことになるが，Lowry法の発色はペプチド 結合だけでなく, チロシンやトリプトファンといったア ミノ酸残基によって発色することが知られている。しか しながら, 塩素処理濃度が高くなるにつれて, タンパク 質の濃度が減少, 寸なわちローリー法の発色が弱まって いることから，アミノ酸残基による影響はないと考えら れる. なお，脂質は定量下限值以下であった。

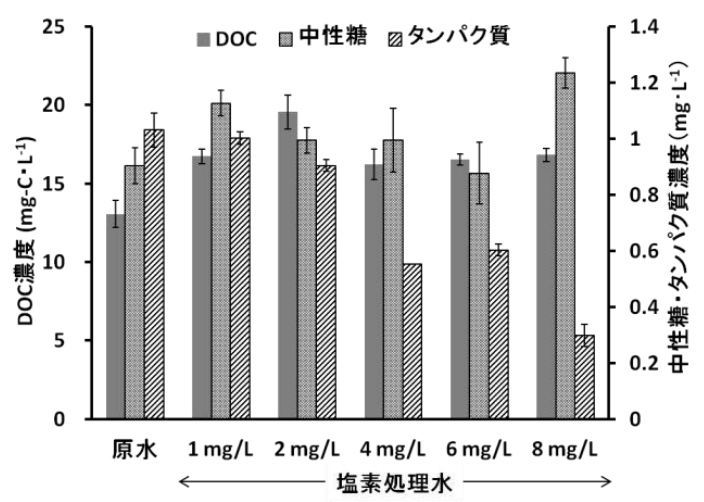

図-1 有機物組成分析結果

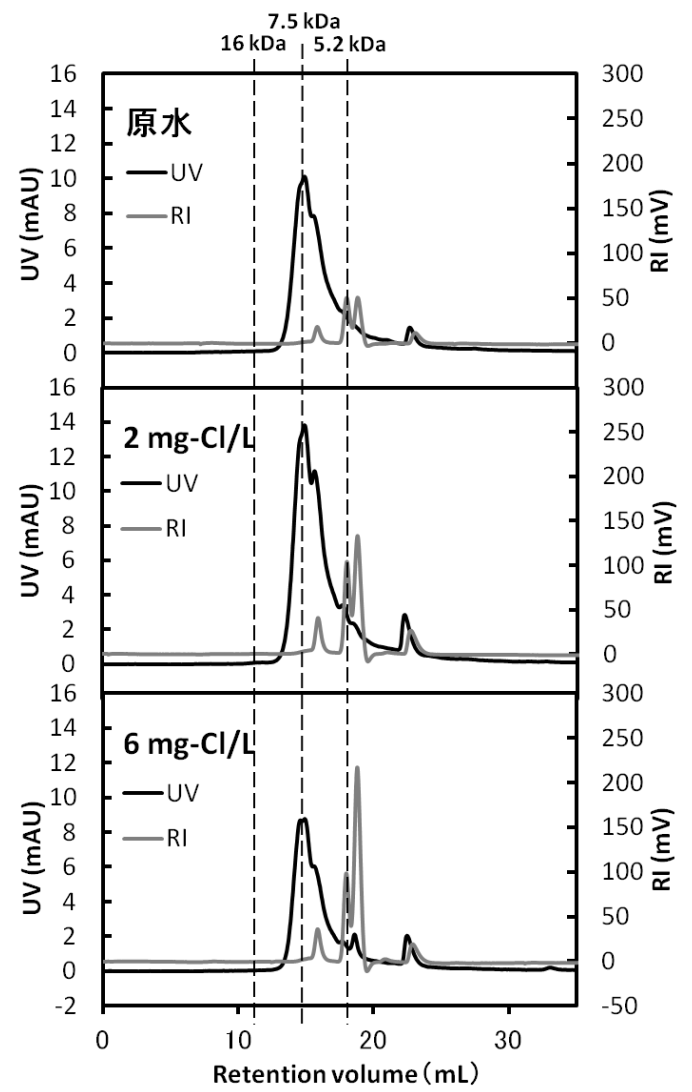

\section{(2) 分子量分画結果}

試料水中の分子量分布を把握するために行った分子量 分画結果を図-2に示した. 全ての分子量分画結果におい て， $7.5 \mathrm{kDa}$ 付近， $5.2 \mathrm{kDa}$ 付近及び，それ以下の分子量に おいてUV（280 nm）及び示差屈折率のピークを示した。 UVは280 nmの波長で観測しており, タンパク質中の芳 香族アミノ酸 (ベンゼン環) に由来する紫外吸収を測定 している. 一方で, 示差屈折率は, UV検出器において 検出できない糖，アルコール，無機イオンなど試料水に 溶存している全ての物質に対し反応寸る. 図-2より，原 水においては, $7.5 \mathrm{kDa}$ 付近でUVが大きなピークを示し た. 塩素処理量 $1-4 \mathrm{mg} \cdot \mathrm{L}^{-1}$ では, 塩素濃度に応じて $7.5 \mathrm{kDa}$ 付近のピークが増大したことに対し, 塩素処理量4-8 $\mathrm{mg} \cdot \mathrm{L}^{-1}$ では, 塩素濃度に応じて7.5 kDa付近のピークが減 少した。 これは, 塩素処理により藻類や微生物が影響を 受け，有機物が水中に放出された一方で，タンパク質の ペプチド結合が切断されたためと考えられる. 逆に, $5.2 \mathrm{kDa}$ 付近では, 塩素処理水において新たなUVのピー クが出現しており, 塩素処理によって一部のタンパク質 の分子量が7.5 kDaから5.2 kDa付近へ変化したと考えられ る. これは, 前節の組成分析結果において, 高濃度の塩

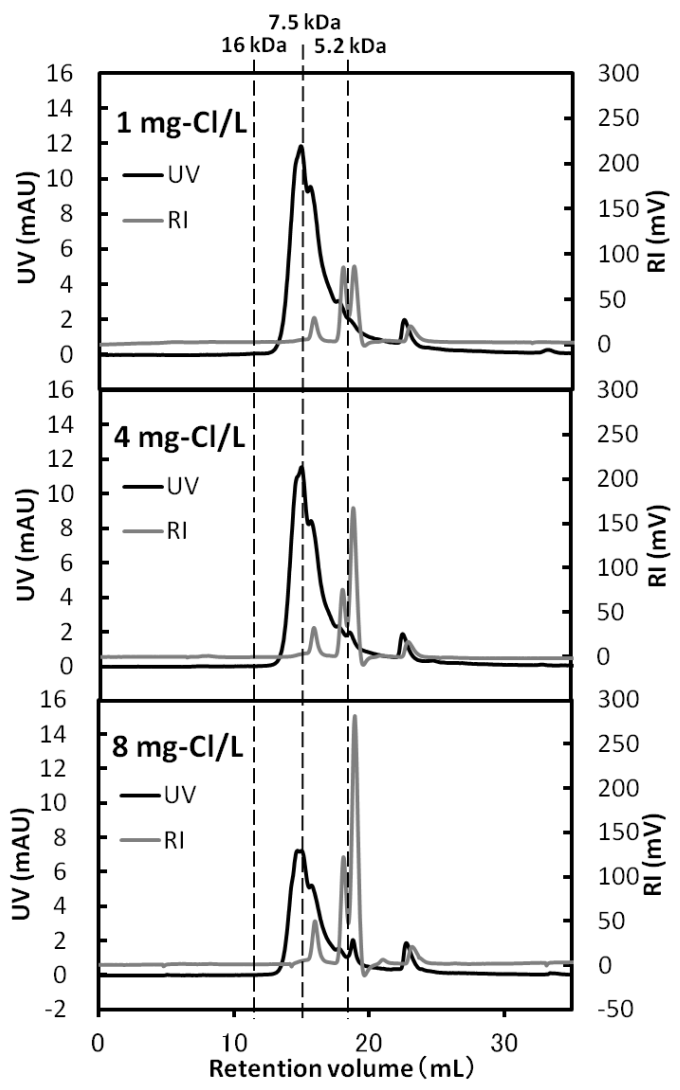

図-2 分子量分布結果 
素処理によってタンパク質濃度が減少していること, す なわちタンパク質のペプチド結合が切断され細分化され たとする考察を後押しする結果である. 一方で, 示差屈 折率に着目すると， $5.2 \mathrm{kDa}$ 付近のピークが非常に大き くなっていることが示された. この示差屈折率のピーク の上昇は5.2 kDa付近のタンパク質が増加したことによる と考えられる．また，UVと示差屈折率の測定值は芳香 族アミノ酸の種類や試料水の組成によって異なるため一 概には言えないが, $5.2 \mathrm{kDa}$ 付近のUVの上昇に対して, 示差屈折率は非常に大きく上昇していることから, タン パク質だけでなく, 糖類やその他の有機物も増加してい ると考えられる.

\section{(3) 膜万過実験結果}

小型膜ろ過器を用いて計測した，原水及び1，2，4，6, $8 \mathrm{mg} \cdot \mathrm{L}^{-1}$ 塩素処理水の膜ろ過実験結果に関して, 原水及 び1，2，6 $\mathrm{mg} \cdot \mathrm{L}^{-1}$ 塩素処理水を用いた結果を抜粋して図3に示した. 万過後の残留塩素濃度は $1 \mathrm{mg} \cdot \mathrm{L}^{-1}$ 塩素処理水 で $0.1 \mathrm{mg} \cdot \mathrm{L}^{-1}, 2 \mathrm{mg} \cdot \mathrm{L}^{-1}$ 塩素処理水 素処理水で $2.0 \mathrm{mg} \cdot \mathrm{L}^{-1}$ 以上であった. 図-3より，原水を用 いた場合の膜間差圧がおよそ $250 \mathrm{~min}$ で100 kPaに達したの に対して，塩素処理水を用いた場合では，膜間差圧は

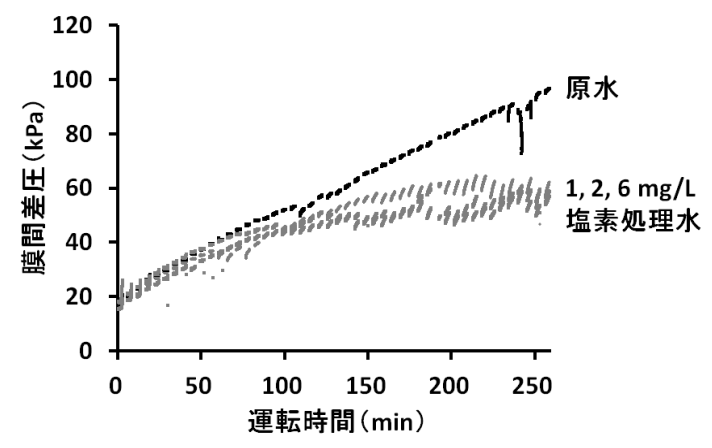

図-3 膜万過実験結果

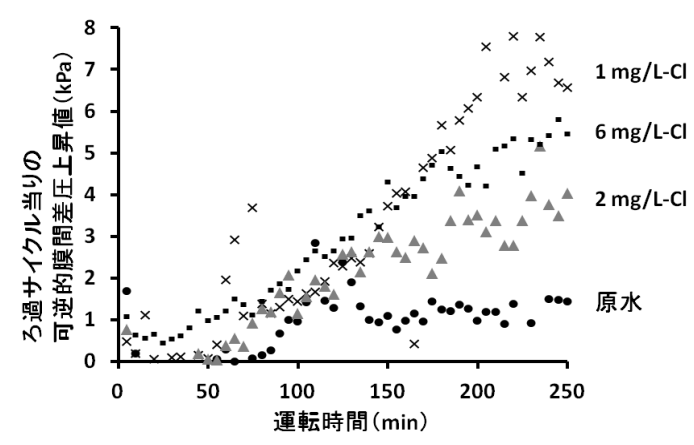

図-4 万過サイクル当りの可逆的膜間差圧 上昇值の推移
40-60 kPa程度にとどまったことから，前塩素処理によっ て不可逆的膜ファウリングが抑制されたことが示された. また，原水及び $1 ， 2,6 \mathrm{mg} \cdot \mathrm{L}^{-1}$ 塩素処理水に対するろ 過サイクル当りの可逆的膜間差圧上昇值の推移を図-4に 示した．図-4より，原水を用いた場合に比べて，前塩素 処理を行うことで可逆的膜ファウリングが進展している ことが示された. 一般に, 膜孔径よりも小さな粒子は膜 孔の奥に侵入するため不可逆的膜ファウリングを招き, 一方, 膜孔径よりも大きな微粒子は膜面上に堆積寸るの で逆洗などで排除しやすく, 可逆的膜ファウリングを引 き起す. 本実験の前塩素処理により, 不可逆的膜ファウ リングが抑制され，可逆的膜ファウリングが増加したこ とは，懸濁物質の粒子サイズが膜孔径よりも小さなサイ ズから大きなサイズに変化したためと考えられる，本実 験では膜ろ過前段に凝集を行っていることから, 前塩素 処理によりフロックの形成状況が変化したことが推測さ れる.

前節の化学組成分析結果より, 塩素処理を行うこと で不飽和結合を有する有機物が減少した一方で, DOC 濃度及び中性糖濃度が増加することが示された。これは, 塩素処理により藻類が何らかの影響を受けたことで, 有 機物の性状が変化したと考えられる. 寸なわち, 前塩素 処理による有機物の性状の変化が，凝集段階でのフロッ クの形成に影響を与えたことで, 不可逆的膜ファウリン グから可逆的膜ファウリングへ変移したと考えられる.

また, 分子量分画結果より, 塩素処理が有機物を低 分子化していることが示されたが，分子量分画により測 定された $5.2 \mathrm{kDa}$ 及び7.5 kDa程度の分子量は, 精密ろ過膜 の孔径 $(0.1 \mu \mathrm{m}$ 程度) 以下であり, フロックに取り込ま れなければいずれも膜細孔に蓄積することとなる.

一方, 残留塩素が確保されることにより, 膜自体一 の洗浄効果によって膜ファウリングが抑制されたとも考 えられる. 既往の研究においても, 前塩素処理を行うこ とにより膜ファウリングが抑制され，塩素による抑制効 果が働いたことが報告されている30).

以上の結果より, 塩素添加による有機物の変性や不 飽和結合の解消，タンパク質の低分子化が，フロック粒 径の増大につながる考察として, 次の3つの要因が考え られる.

1つ目の要因としては, 高分子量の藻類由来有機物質 による凝集フロックへの保護コロイド作用が，塩素処理 による低分子化の影響により抑制され，結果として凝集 効率が上昇したことが考えられる。菅原ら ${ }^{31}$ は $M$. aeruginosaの細胞外有機物質（EOM）について検討を行 い，低分子量画分は除去されずに残留するが但しカオリ ンの凝集を阻害はしないこと, 高分子量画分は凝集剤に より生じた微小フロックの粒子表面に吸着することで保 
護コロイド作用を及ぼし, 微小フロック間の架橋作用が 阻害されることを報告している．高分子画分の方が凝集 阻害に寄与寸る程度が高いという知見は, Bernhardtら ${ }^{32}$ がDictyosphaerium sp.のEOMを用いて行った実験において も同様の結果が得られている.

2つ目の要因としては, 藻類含有水への塩素添加によ るゼータ電位低下の影響が考えられる。福島ら ${ }^{33}$ は Nitzschia sp. とPhormidium sp.に対して, 塩素処理前後の藻 類細胞のゼータ電位を測定し, 藻類によっては塩素処理 によってゼータ電位の絶刘值が低下したことを報告して いる.

3つ目の要因としては, 塩素による殺藻効果による凝 集改善効果である. 藻類種によっては, 気泡を持つこと で細胞密度が低く, フロックを形成しても沈殿しないた め, 殺藻により細胞を破壊することで, 凝集効率が改善 することが知られている. また，藻類細胞表面に保持さ れる物質は凝集剂と接することになり，フロック形成一 影響すると考えられるが，塩素により細胞が破壊される ことで, 凝集効率に影響寸ると考えられる.

よって, 以上の考察から, 本研究において前塩素処 理により不可逆的膜ファウリングが抑制されたことは, 前塩素処理によって有機物の性状が変化したこと及び低 分子化したことで, 凝集フロックの形成に影響を与えた ためと推測された.

\section{4. おわりに}

AOM由来の膜ファウリングに対する前塩素処理の影 響を検討するため, 本研究では塩素処理前後の有機物変 化に着目した．有機物組成分析の結果，塩素処理後に DOCや糖類が増加していることから, 塩素処理が藻類 や微生物に影響を与え, 有機物の性状を変化させたこと が考えられた. 一方で, 高濃度の塩素処理によってタン パク質のペプチド結合が切断されたことが示唆され，分 子量分画結果からも, タンパク質が塩素処理により低分 子化されたことが示された. 膜ろ過実験の結果から, 前 塩素処理によって膜ファウリングが抑制されたことが示 されたが，その主要因として，塩素処理により有機物の 性状が変化したことで凝集フロックの形成に影響を与え, 不可逆的膜ファウリングが抑制された可能性が示唆され た.

\section{参考文献}

1) Jacangelo J. G., Adham S. S. and Laine J. M.: MECHANISM OF CRYPTOSPORIDIUM, GIARDIA, AND MS2 VIRUS REMOVAL BY MF AND UF, Journal American Water Works Association, Vol. 87,
No. 9, pp. 107-121, 1995.

2) Cleveland C. T.: Big advantages in membrane filtration, Joumal American Water Works Association, Vol.91, No. 6, pp. 10-10, 1999.

3) Lerch A., Panglisch S., Buchta P., Tomita Y., Yonekawa H., Hattori K. and Gimbel R: Direct river water treatment using coagulation/ceramic membrane microfiltration. Desalination, Vol. 179, No. 1-3, pp. 41-50, 2005.

4) Kimura K., Maeda T., Yamamura H. and Watanabe Y.: Irreversible membrane fouling in microfiltration membranes filtering coagulated surface water, Joumal of Membrane Science, Vol. 320, No. 1-2, pp. 356-362, 2008.

5) Yamamura H., Kimura K. and Watanabe Y.: Mechanism involved in the evolution of physically irreversible fouling in microfiltration and ultrafiltration membranes used for drinking water treatment, Environmental Science \& Technology, Vol.41, No. 19, pp. 6789-6794, 2007.

6) Lee N. H., Amy G., Croue J. P. and Buisson H.: Identification and understanding of fouling in low-pressure membrane (MF/UF) filtration by natural organic matter (NOM), Water Research, Vol. 38, No. 20, pp. 45114523, 2004.

7) 木村克輝, 羽根康史, 渡部義公 : 河川水 UF 膜ろ過における 不可逆的膜ファウリングに及ぼす前凝集沈殿の影響, 土木 学会第 58 回年次学術講演会講演集, 2003.

8) Tambo N. and Kamei T.: TREATABILITY EVALUATION OF GENERAL ORGANIC-MATTER - MATRIX CONCEPTION AND ITS APPLICATION FOR A REGIONAL WATER AND WASTEWATER SYSTEM, Water Research, Vol. 12, No. 11, pp.931-950, 1978.

9) 木村克輝, 羽根康史, 渡部義公 : 河川水 UF膜万過における 不可逆的膜ファウリングに及ぼす前凝集沈殿の影響, 土木 学会第 58 回年次学術講演会講演集, 2003.

10) Kimura K., Yamamura H. and Watanabe Y.: Irreversible fouling in MF/UF membranes caused by natural organic matters (NOMs) isolated from different origins, Separation Science and Technology, Vol. 41, No. 7, pp. 1331-1344, 2006.

11) Kimura K., Hane Y., Watanabe Y., Amy G. and Ohkuma N.: Imeversible membrane fouling during ultrafiltration of surface water, Water Research, Vol.38, No. 14-15,pp. 3431-3441, 2004.

12) Henderson R. K., Baker A., Parsons S. A. and Jefferson B.: Characterisation of algogenic organic matter extracted from cyanobacteria, green algae and diatoms, Water Research, Vol. 42, No. 13, pp. 3435-3445, 2008.

13) Pereira S., Zille A., Micheletti E., Moradas-Femeira P., De Philippis R. and Tamagnini P.: Complexity of cyanobacterial exopolysaccharides: composition, structures, inducing factors and putative genes involved in their biosynthesis and assembly, Fems Microbiology Reviews, Vol. 33, No. 5, pp. 917-941, 2009.

14) Chiou Y. T., Hsieh M. L. and Yeh H. H.: Effect of algal extracellular polymer substances on UF membrane fouling, Desalination, Vol. 250, No. 2,pp. 648-652, 2010.

15) Babel S. and Takizawa S.: Microfiltration membrane fouling and cake 
behavior during algal filtration, Desalination, Vol. 261, No. 1-2, pp. 46-51, 2010.

16) Her N., Amy G., Park H. R. and Song M.: Characterizing algogenic organic matter (AOM) and evaluating associated NF membrane fouling, Water Research, Vol. 38, No. 6, pp. 1427-1438, 2004.

17) Lee N., Amy G. and Croue J. P.: Low-pressure membrane (MF/UF) fouling associated with allochthonous versus autochthonous natural organic matter, Water Research, Vol. 40, No. 12,pp. 2357-2368, 2006.

18) Campinas M. and Rosa M. J.: Evaluation of cyanobacterial cells removal and lysis by ultrafiltration, Separation and Purification Technology, Vol. 70, No. 3,pp. 345-353, 2010.

19) Plummer J. D. and Edzwald J. K.: Effects of chlorine and ozone on algal cell properties and removal of algae by coagulation, Journal of Water Supply Research and Technology-Aqua, Vol.51, No. 6, pp. 307-318, 2002.

20) Henderson R., Parsons S. A. and Jefferson B.: The impact of algal properties and pre-oxidation on solid-liquid separation of algae, Water Research, Vol. 42, No. 8-9, pp. 1827-1845, 2008.

21) Lenore S. C., Amold E. G., Andrew D. E.: Standard Methods for the Examination of Water and Wastewater 20th edition, American Public Health Association, Method 5910, 1999.

22) Wilson A. D.: THE MICRO-DETERMINATION OF FERROUS IRON IN SILICATE - MINERALS BY A VOLUMETRIC AND A COLORIMETRIC METHOD, Analyst, Vol. 85, No. 1016, pp. 823-827, 1960.

23) Lenore, S. C., Amold, E. G., Andrew, D. E.: Standard Methods for the Examination of Water and Wastewater 20th edition, American Public Health Association, Method 3500, 1999.

24) Goto, K., Taguchi, S., Fukue, Y., Ohta, K. and Watanabe, H.: SPECTROPHOTOMETRIC DETERMINATION OF MANGANESE WITH 1-(2-PYRIDYLAZO)-2-NAPHTHOL AND A NONIONIC SURFACTANT, Talanta, Vol. 24, No. 12, pp. 752-753, 1977.

25) 雨宮由美子，中山大樹 : 藍藻 Microcystis より単離した粘質
鞘物質の化学的性質と金属類に対する吸着特性，日本陸水 学会雑誌, Vol.45,No.3,pp. 187-193, 1984.

26) 福井作蔵 : 生物化学実験法 1 還元糖の定量法, 学会出版 センター, 1969.

27) Dubois M., Gilles K. A., Hamilton J. K., Rebers P. A. and Smith F. COLORIMETRIC METHOD FOR DETERMINATION OF SUGARS AND RELATED SUBSTANCES, Analytical Chemistry, Vol. 28, No. 3 , pp. 350-356, 1956.

28) Lowry O. H., Rosebrough N. J., Farr A. L. and Randall R. J.: PROTEIN MEASUREMENT WITH THE FOLIN PHENOL REAGENT, Joumal of Biological Chemistry, Vol. 193, No. 1,pp. 265-275, 1951.

29) Spayd R.W., Bruschi B., Burdick B. A., Dappen G. M., Eikenberry J. N., Esders T. W., Figueras J., Goodhue C. T., Larossa D. D., Nelson R. W., Rand R. N. and Wu T. W.: MULTILAYER FILM ELEMENTS FOR CLINICAL ANALYSIS - APPLICATIONS TO REPRESENTATIVE CHEMICAL DETERMINATIONS, Clinical Chemistry, Vol. 24, No. 8, pp. 1343-1350, 1978.

30) 貝谷吉英, 伊藤義一, 滝沢智, 藤田賢二, 多川正 : 浄水処 理に使用した膜の污染物質に関する研究（3）前塩素処理の 膜污染抑制効果，水道協会雑誌，Vol. 68, No. 10, pp. 15-20, 1999.

31) 菅原繁, 黒川眞弓, 胡建英, 眞柄泰基 : カオリン人工濁水の凝 集沈殿に与える藻類由来有機物質の分子量の影響，水道協 會雜誌，Vol.66， No.8，pp.9-18， 1997.

32) O. Hoyer O. L " usse H. Bernhardt and H. Schell: INFLUENCE OF ALGOGENIC ORGANIC SUBSTANCES ON FLOCCULATION ANDFILTRATION.WISA, Vol. 1,pp.175-182, 1991.

33) 福島健市, 今野弘, 鶯出 貴 : 藍藻類と珪藻類への塩素処理 による影響の比較，第 59 回土木学会全国大会，2004.

(2012.5. 25 受付)

Effect of Pre-chlorination on Ceramic Membrane Fouling Caused by Algal Organic Matter

\title{
Tetsuya YAMAKI ${ }^{1}$, Jae-Lim LIM $^{2}$, Yasunori YOSHIHARA ${ }^{3}$, Hitoshi YONEKAWA ${ }^{3}$ and Tatsuo OMURA ${ }^{1}$
}

\author{
${ }^{1}$ Dept. of Civil and Environmental Engineering, Tohoku University \\ ${ }^{2}$ Korea Water Resources Corporation \\ ${ }^{3}$ METAWATER Co., Ltd.
}

\begin{abstract}
Algal organic matter (AOM) is one of the factors causing membrane fouling in microfiltration, and prechlorination can control membrane fouling by AOM. To evaluate effect of pre-chlorination on membrane fouling by AOM in ceramic membrane treatment, chemical characterization and molecular weight distribution before and after pre-chlorine treatment $\left(1-8 \mathrm{mg} \cdot \mathrm{L}^{-1}\right)$ were analyzed. As a result, concentrations of DOC and neutral sugar increased in all chlorination conditions, while those of protein after chlorination at $4-8 \mathrm{mg} \cdot \mathrm{L}^{-1}$ decreased. Moreover, molecular weight distribution showed that main
\end{abstract}


peak shifted from $7.5 \mathrm{kDa}$ to $5.2 \mathrm{kDa}$ after chlorination. In microfiltration test, all chlorine treatment (1-8 $\mathrm{mg} \cdot \mathrm{L}^{-1}$ ) reduced the membrane fouling. From these results, it is suggested that membrane fouling by AOM was controlled by chlorination because it denatured AOM and varied flock size. 